\title{
PENGARUH KEBERADAAN MANGROVE TERHADAP KERAGAMAN MAKROBENTOS DI TAMBAK SEKITARNYA
}

\author{
Gunarto", A. Marsambuana Pirzan"), Suharyanto", Rohama Daud"), dan Burhanuddin")
}

\begin{abstract}
ABSTRAK
Penelitian dilakukan di Dusun Pangasa dan Dusun Tongke-Tongke, Desa Samataring, Kabupaten Sinjai, Sulawesi Selatan. Kedua dusun tersebut mempunyai hutan mangrove yang berbeda luasnya. Tujuan penelitian ini adalah untuk mengetahui perbedaan kelimpahan, indeks keragaman $\left(H^{\prime}\right)$, indeks keseragaman $(E)$, dan indeks dominasi $(C)$ makrobentos yang hidup di dalam tanah pertambakan yang di pinggir pantainya mempunyai hutan mangrove sempit (Dusun Pangasa) dan yang di pinggir pantainya mempunyai hutan mangrove luas (Dusun Tongke-Tongke). Pengambilan sampel tanah pada plot-plot ukuran $25 \times 25 \times 10 \mathrm{~cm}^{3}$ yang mewakili tambak dekat sawah, tambak daerah peralihan, tambak dekat hutan mangrove, hutan mangrove, dan di dasar Sungai Sinjai. Sampel tanah disaring dengan saringan nomor 32. Selanjutnya makrobentos yang diperoleh diidentifikasi sampai ke tingkat spesies. Hasil penelitian menunjukkan bahwa nilai H' makrobentos di tambak $(0,47)$ dan mangrove Tongke-Tongke $(0,39)$ cenderung lebih tinggi daripada di tambak Pangasa $(0,30)$; dan di Sungai Sinjai $(0,37)$; namun secara statistik tidak menunjukkan perbedaan yang nyata $(P>0,05)$. Perbedaan yang nyata $(P<0,05)$ hanya terlihat pada nilai E makrobentos di tambak Pangasa dengan yang ada di dasar Sungai Sinjai. Lebih beragamnya spesies makrobentos di Tambak Tongke-Tongke kemungkinan hasil ekspansi dari beragamnya makrobentos yang ada di hutan mangrove Tongke-Tongke.
\end{abstract}

\section{ABSTRACT: The influencing of mangrove availability to the macrobenthos diversity in it surrounding brackishwater pond. By: Gunarto, A. Marsambuana Pirzan, Suharyanto, Rohama Daud, and Burhanuddin}

The research conducted in two sub villages there were Dusun Pangasa and Dusun TongkeTongke Samataring Village, Sinjai Regency, South Sulawesi. Both of sub villages have mangrove stand in the different dense. The objective of the research is to known the differences of abundance, diversity indices $\left(H^{\prime}\right)$, homogeneity indices $(E)$, and dominate indices $(C)$ of macrobenthos there were settle in brackishwater pond soil which it have small fringed (Dusun Pangasa) and large fringed (Dusun Tongke-Tongke) of mangrove dense in their coastal area. Sampling to obtain macrobenthos in the pond soil conducted through grabbed the soil in the plots each size of $25 \times 25 \times 10 \mathrm{~cm}^{3}$ representatives stations which including; the pond area closes with paddy field, the pond in the transition area, the pond area closes to the mangrove stand, inside mangrove area and in the bed of Sinjai River. The soil samples sieves with the sieve number 32 and the macrobenthos obtained preserved to identify to the species level.

Result of the research showed that the $H^{\prime}$ value of macrobenthos in Tongke-Tongke brackishwater ponds $(0.50)$ and in Tongke-Tongke mangrove $(0.39)$ tend to be higher than in Pangasa brackish water ponds $(0.30)$ and in the bed of Sinjai river $(0.37)$, however there were not significantly different $(P>0.05)$. Clear significantly different $(P<0.05)$ was only observed between $E$ value of macrobenthos in Pangasa brackishwater pond and in the bed of Sinjai River. The more varies of macrobenthos in Tongke-Tongke brackish water pond may cause by expansions of most macrobenthos species originally come from mangrove Tongke-Tongke.

KEYWORDS: $\quad$ macrobenthos, diversity, homogeneity, dominate

\section{PENDAHULUAN}

Perkembangan lahan tambak di Indonesia terjadi secara pesat kira-kira sejak tahun 1990-an di mana pada waktu itu budi daya udang dirasa sangat menguntungkan, sehingga masyarakat beramai-ramai berusaha membangun tambak. Pembangunan tambak banyak dilakukan dengan mengkonversi mangrove. Anonim (2001) melaporkan bahwa berdasarkan kajian yang dilakukan oleh Direktorat Jenderal Rehabilitasi Lahan dan Perhutanan Sosial (RLPS) pada tahun 1999, hutan mangrove yang rusak luasnya sekitar 5,3 juta ha (1,6 juta ha rusak dalam kawasan hutan dan 3,7 juta ha rusak di luar kawasan hutan).

Perusakan mangrove, penggunaan pestisida, dan penimbunan bahan organik sisa pakan dari aktivitas budi daya tambak diperkirakan telah berdampak pada

\footnotetext{
-) Peneliti pada Balai Penelitian Perikanan Pantai, Maros
} 
menurunnya biodiversitas kawasan perairan pantai, termasuk berkurangnya keragaman bentos. Padahal berbagai jenis kekerangan dan organisme lainnya yang hidup di kawasan pantai mampu berfungsi sebagai biofilter alami untuk perbaikan lingkungan perairan pantai. Menurut Ahmad (2001), kelebihan pakan dalam budi daya udang dan penghilangan areal mangrove akan memacu berkembangnya bakteri patogen yang pada akhirnya akan menyebabkan kegagalan panen udang.

Untuk pemanfaatan lingkungan pantai agar tetap berkesinambungan maka diperlukan pengetahuan dasar semua faktor-faktor yang saling berkaitan antara satu dengan lainnya. Faktor tersebut adalah bersifat biotik dan abiotik. Faktor biotik adalah faktor yang dihasilkan oleh organisme yang mempengaruhi proses-proses hayati dalam lingkungan perairan pantai. Satu di antara beberapa faktor biotik yang sangat berperan dalam lingkungan perairan pantal adalah bentos. Makrobentos merupakan sumber makanan utama bagi ikan-ikan estuaria dan mempunyai peran dalam siklus nutrien melalui proses detrivory dan bioturbation pada sedimen (Sarpedonti \& Sesakumar, 1997).

Upaya perbaikan lingkungan pantai telah dilakukan oleh masyarakat pantai di Dusun Tongke-Tongke sejak tahun 1986 dengan cara menanam pohon bakau jenis Rhizophora mucronata dan kini telah berhasil karena telah terbentuknya hutan bakau dengan luas sekitar 600 ha. Namun perlu dikaji apakah keberadaan hutan mangrove tersebut berpengaruh terhadap keanekaragaman makrobentos di pertambakan sekitarnya. Tujuan penelitian adalah untuk mengetahui perbedaan kelimpahan, indeks keragaman, indeks keseragaman, dan indeks dominasi makrobentos di kawasan tambak yang di pinggir pantainya mempunyai hutan mangrove sempit (tambak Dusun Pangasa) dan kawasan tambak yang di pinggir pantainya mempunyai hutan mangrove luas (tambak Dusun Tongke-Tongke).

\section{BAHAN DAN METODE}

Penelitian dilakukan di Desa Samataring, Kabupaten Sinjai, Sulawesi Selatan, mencakup dua kawasan yaitu Dusun Pangasa dengan hutan mangrove yang tipis (ketebalan $25 \mathrm{~m}$ dan luas $1 \mathrm{ha}$ ) dan Dusun Tongke-Tongke dengan hutan mangrove yang tebal (ketebalan 300 m dan luas sekitar 600 ha). Hutan mangrove merupakan hasil reboisasi masyarakat setempat dan umur tanaman bakau bervariasi antara $14-16$ tahun. Di bagian sebelah dalam kedua hutan mangrove tersebut terdapat hamparan tambak yang digunakan untuk budi daya udang dan bandeng.

Pengambilan sampel makrobentos di masingmasing lokasi dilakukan dengan cara membuat garis transek tegak lurus garis pantai dari areal pertambakan dekat sawah hingga ujung hutan mangrove yang langsung menghadap ke laut. Panjang total garis transek sekitar $1.800 \mathrm{~m}$, selanjutnya dibuat stasiun-stasiun. Pada setiap stasiun dibuat plot-plot ukuran $25 \times 25 \times 10 \mathrm{~cm}^{3}$ untuk pengambilan sampel tanah yang mewakili tambak dekat sawah, tambak daerah peralihan, dan tambak dekat hutan mangrove. Khusus di mangrove Tongke-Tongke dibuat stasiun hutan mangrove $0 \mathrm{~m}$ dari garis pantai, hutan mangrove 150 m dari garis pantai, dan hutan mangrove $300 \mathrm{~m}$ dari garis pantai. Sedangkan di Pangasa hanya dibuat satu stasiun hutan mangrove karena ketebalan hutan mangrove hanya sekitar $25 \mathrm{~m}$.

Pengambilan sampel makrobentos juga dilakukan di Sungai Sinjai yang berada dekat hutan mangrove tersebut menggunakan eckman grab ukuran $20 \times 20$ $\mathrm{cm}^{2}$ (Rejeki \& Ahmad, 1991). Ditentukan tiga stasiun di sungai untuk pengambilan makrobentos yaitu stasiun $1 \mathrm{~km}$ sebelum muara, stasion peralihan dan stasiun mulut muara. Posisi dan lokasi stasiun untuk pengambilan sampel dapat dilihat pada Tabel 1.

Sampel-sampel tanah tersebut selanjutnya disaring menggunakan saringan Nomor: 32. Makrobentos yang diperoleh diidentifikasi berdasarkan kunci identifikasi dari Abbott (1992); Dharma (1988, 1992); dihitung jumlah total setiap spesies dan ditimbang biomassa dari setiap spesies dari masing-masing stasiun. Selanjutnya dihitung nilai indeks keragaman, indeks keseragaman, dan indeks dominasi makrobentos dari Shanon-Wiener (Krebs, 1978 dalam Odum, 1963). Rumus yang digunakan adalah sebagai berikut:

Indeks Keragaman Jenis:

$$
\begin{aligned}
\mathrm{H}^{\prime}=-\sum \mathrm{Pi} \log _{2} \mathrm{Pi}^{\mathrm{H}^{\prime}} & =\text { Indeks Keragaman Jenis } \\
\mathrm{Pi}=\frac{\mathrm{ni}}{\mathrm{Ni}} & =\text { Jumlah individu taksa ke }-\mathrm{i} \\
\mathrm{N} & =\text { Jumlah total individu }
\end{aligned}
$$

Indeks Keseragaman Jenis:

$$
\begin{aligned}
& E=\frac{H^{\prime}}{H \max } \quad \begin{array}{ll}
H^{\prime} & =\text { Indeks Keseragaman Jenis } \\
& =\text { Indeks Keragaman Jenis }
\end{array} \\
& \mathrm{H} \max =\log _{2} \mathrm{~S} \quad \mathrm{H} \max =\text { NilaiKeragaman Maksimum }
\end{aligned}
$$

Indeks Dominasi Jenis:

$$
C=\sum\left(\frac{n i}{N}\right)^{2} \quad \begin{aligned}
& C=\text { Indeks Domin asi } \\
& n i=J u m l a h \text { ndividu taksa } k e-i
\end{aligned}
$$

Untuk mengetahui perbedaan lokasi mana yang mempunyai nilai H' dan E tinggi, maka data nilai H' dan E dari Tambak Pangasa, Tambak Tongke-Tongke, 
Tabel 1. Stasiun di kawasan tambak dan mangrove untuk pengambilan makrobentos Table 1. Station in brackish water pond and mangrove area to collect dwelling of macrobenthos

\begin{tabular}{|c|c|c|}
\hline $\begin{array}{l}\text { Stasiun } \\
\text { Station }\end{array}$ & $\begin{array}{c}\text { Sistem Posisi Geografis } \\
\text { (SPG) } \\
\text { Geographical Position } \\
\text { System (GPS) }\end{array}$ & $\begin{array}{l}\text { Lokasi sampling } \\
\text { Sampling location }\end{array}$ \\
\hline 1 & $\begin{array}{l}51 \mathrm{M} 0196775 \\
\text { UTM9432001 }\end{array}$ & Tambak Pangasa (dekat kampung) \\
\hline 2 & $\begin{array}{l}51 M 0197094 \\
\text { TM9431857 }\end{array}$ & Tambak Pangasa (bagian tengah) \\
\hline 3 & $\begin{array}{l}\text { 51M0197457 } \\
\text { UTM9431480 }\end{array}$ & Tambak Pangasa (dekat mangrove) \\
\hline 4 & $\begin{array}{l}\text { 51M0197465 } \\
\text { UTM9431125 }\end{array}$ & Mangrove Pangasa \\
\hline 5 & $\begin{array}{l}\text { 51M0196883 } \\
\text { UTM9430164 }\end{array}$ & Tambak Tongke-Tongke (dekat sawah) \\
\hline 6 & $\begin{array}{l}51 M 0197245 \\
\text { UTM9430171 }\end{array}$ & Tambak Tongke-Tongke (bagian tengah) \\
\hline 7 & $\begin{array}{l}\text { 51M0197465 } \\
\text { UTM9430146 }\end{array}$ & Tambak Tongke-Tongke (dekat mangrove) \\
\hline 8 & $\begin{array}{l}\text { 51M0197564 } \\
\text { UTM9430081 }\end{array}$ & MangroveTongke-Tongke ( $0 \mathrm{~m}$ dari garis pantai) \\
\hline 9 & $\begin{array}{l}51 M 0197652 \\
\text { UTM9430416 }\end{array}$ & MangroveTongke-Tongke ( $150 \mathrm{~m}$ dari garis \\
\hline 10 & $\begin{array}{l}\text { 51M0197431 } \\
\text { UTM9430385 }\end{array}$ & MangroveTongke-Tongke ( $300 \mathrm{~m}$ dari garis \\
\hline 11 & $\begin{array}{l}\text { 51M0196383 } \\
\text { UTM9432571 }\end{array}$ & Sungai Sinjai (1 km sebelah dalam muara) \\
\hline 12 & $\begin{array}{l}\text { 51M0197386 } \\
\text { UTM9432224 }\end{array}$ & Sungai Sinjai (500 m sebelah dalam muara) \\
\hline 13 & $\begin{array}{l}51 \text { M0197793 } \\
\text { UTM9431547 }\end{array}$ & Sungai Sinjai ( muara) \\
\hline
\end{tabular}

Hutan Bakau Tongke-Tongke, dan Sungai Sinjai dianalisis dengan analisis varian (Fowler \& Cohen, 1990).

Untuk mengetahui kualitas tanah dan air maka sampel tanah dan air diambil di setiap stasiun. Analisis tanah dilakukan terhadap beberapa parameter yaitu $\mathrm{pH}\left(\mathrm{pH} \mathrm{KCl}\right.$ dan $\left.\mathrm{pH} \mathrm{H}_{2} \mathrm{O}\right), \mathrm{Fe}, \mathrm{SO}_{4}$, bahan organik (ignition loss) (Melville, 1993); serta tekstur tanah (Menon, 1973). Sedangkan analisis kualitas air terdiri atas $\mathrm{pH}$ diukur dengan $\mathrm{pH}$-meter, salinitas diukur dengan refraktometer merk Atago, BOT, COD, alkalinitas, $\mathrm{Fe}, \mathrm{NH}_{3}-\mathrm{N}, \mathrm{NO}_{2}-\mathrm{N}, \mathrm{NO}_{3}-\mathrm{N}, \mathrm{PO}_{4}-\mathrm{P}$ (Haryadi et al., 1992).

\section{HASIL DAN BAHASAN}

Kepadatan (ind. $\left./ \mathrm{m}^{2}\right)$, indeks keragaman $\left(\mathrm{H}^{\prime}\right)$, indeks keseragaman (E), dan indeks dominasi (C) merupakan parameter dasar dalam mengetahui suatu komunitas. Indeks ini menunjukkan kekayaan jenis dalam suatu komunitas serta memperlihatkan keseimbangan dalam pembagian jumlah individu setiap jenis (Odum, 1971). Nilai H', E, dan C makrobentos di tambak, hutan bakau dan dasar sungai dapat dilihat di Tabel 2.

Di Tambak Desa Pangasa, yaitu pada stasiun 1 hingga stasiun 3 , nilai $\mathrm{H}^{\prime}$ dan $\mathrm{E}$ tertinggi adalah di stasiun 2 yaitu 0,35 dan 0,73 . Sedangkan nilai $C$ tertinggi di stasiun 3 dan didominasi oleh Cerithidea cingulata dengan kepadatan 220 ind. $/ \mathrm{m}^{2}$ (Gambar 1). Di stasiun 4 yaitu stasiun hutan mangrove di Dusun Pangasa ternyata nilai $H^{\prime}, E$, dan $C$ lebih rendah berbanding di tambak (stasiun 1, 2, dan 3). Hal ini kemungkinan akibat cemaran dari pembabatan mangrove yang sedang berlangsung pada waktu penelitian ini dilakukan. 
Tabel2. Indeks Keragaman, Indeks Keseragaman, dan Indeks Dominasi makrobentos di tambak dan mangrove di Kabupaten Sinjai

Table 2. Diversity Indices, Homogenity Indices, and Dominaty Indices of macrobenthos found in brackishwaters pond and mangrove of Sinjai Regency

\begin{tabular}{|c|c|c|c|}
\hline $\begin{array}{l}\text { Stasiun } \\
\text { Station }\end{array}$ & $\begin{array}{l}\text { Indeks } \\
\text { Keragaman (H') } \\
\text { Diversity Indices }\end{array}$ & $\begin{array}{c}\text { Indeks } \\
\text { Keseragaman (E) } \\
\text { Homogenity Indices }\end{array}$ & $\begin{array}{l}\text { Indeks Dominansi } \\
\text { (C) } \\
\text { Dominaty Indices }\end{array}$ \\
\hline \multicolumn{4}{|c|}{$\begin{array}{c}\text { Tambak Pangasa } \\
\text { Pangasa brackishwater pond }\end{array}$} \\
\hline $\begin{array}{l}1 \\
2\end{array}$ & 0.26 & 0.54 & 0.46 \\
\hline $\begin{array}{l}2 \\
3\end{array}$ & 0.35 & 0.73 & 0.54 \\
\hline$\frac{3}{\text { Rata-rata (Mean) }}$ & 0.30 & 0.50 & 0.65 \\
\hline Rata-rata (Mean) & 0.30 & 0.59 & 0.55 \\
\hline \multicolumn{4}{|l|}{ Hutan bakau Pangasa } \\
\hline 4 & 0.15 & 0.25 & 0.42 \\
\hline \multicolumn{4}{|c|}{$\begin{array}{c}\text { Tambak Tongke-Tongke } \\
\text { Tongke-Tongke } \\
\text { brackishwater pond }\end{array}$} \\
\hline 5 & 0.41 & 0.86 & 0.43 \\
\hline 6 & 0.54 & 0.64 & 0.34 \\
\hline 7 & 0.46 & 0.46 & 0.50 \\
\hline Rata-rata (Mean) & 0.47 & 0.65 & 0.42 \\
\hline \multicolumn{4}{|c|}{ Hutan bakau Tongke-Tongke } \\
\hline \multicolumn{4}{|c|}{ Tongke-Tongke mangrove } \\
\hline 8 & 0.28 & 0.71 & 0.61 \\
\hline 9 & 0.46 & 0.55 & 0.45 \\
\hline 10 & 0.46 & 0.77 & 0.41 \\
\hline Rata-rata (Mean) & 0.39 & 0.68 & 0.49 \\
\hline \multicolumn{4}{|l|}{$\begin{array}{l}\text { Sungai Sinjai } \\
\text { Sinjai River }\end{array}$} \\
\hline 11 & 0.28 & 0.93 & 0.55 \\
\hline 12 & 0.54 & 0.90 & 0.33 \\
\hline 13 & 0.30 & 1.00 & 0.51 \\
\hline Rata-rata (Mean) & 0.37 & 0.94 & 0.46 \\
\hline
\end{tabular}

Di tambak Tongke-Tongke yaitu di stasiun 5 hingga stasiun 7 , nilai $H^{\prime}$ tertinggi di stasiun 6 dan nilai $\mathrm{C}$ tertinggi di stasiun 7, didominasi oleh Rhinoclavis aspera dengan kepadatan 380 ind. $/ \mathrm{m}^{2}$ (Gambar 2). $\mathrm{Hal}$ ini menunjukkan bahwa nilai $\mathrm{H}^{\prime}$ tertinggi adalah pada tambak yang terletak di bagian tengah yaitu di antara tambak yang terletak dekat persawahan dan tambak yang terletak di daerah yang langsung berbatasan dengan keberadaan hutan mangrove. Sedangkan nilai $\mathrm{C}$ tertinggi adalah pada tambak yang terletak langsung berbatasan dengan hutan mangrove (stasiun 7).

Pengamatan makrobentos di hutan bakau pada stasiun 8 hingga stasiun 10, menunjukkan bahwa terdapat perbandingan terbalik antara nilai $\mathrm{H}^{\prime}$ dan nilai $\mathrm{C}$, di mana nilai $\mathrm{H}^{\prime}$ semakin tinggi ke arah laut $(0,28-$ $0,46)$; sedangkan nilai $C$ semakin menurun ke arah laut $(0,61-0,41)$. Hal ini sesuai yang dikemukakan oleh Sarpedonti \& Sesakumar (1997) bahwa semakin ke arah laut maka distribusi makrobentos tidak lagi 
homogen, tetapi semakin melimpah keanekaragaman spesiesnya.

Di stasiun 8, (stasiun hutan mangrove yang terletak pada garis pantai) di dominasi oleh Saccostrea cucullata dan Clypeomorus corallium masing-masing dengan kepadatan 32 ind. $/ \mathrm{m}^{2}$ dan 68 ind. $/ \mathrm{m}^{2}$ (Gambar 3). Pada stasiun sungai yaitu dari $1 \mathrm{~km}$ sebelum muara hingga mulut muara sungai (stasiun 11, 12, dan 13);
Berdasarkan analisis statistik diketahui bahwa nilai $\mathrm{H}^{\prime}$ dari tambak Pangasa, tambak Tongke-Tongke, mangrove Tongke-Tongke, dan Sungai Sinjai tidak menunjukkan perbedaan yang nyata $(P>0,05)$; namun ada kecenderungan bahwa nilai $\mathrm{H}^{\prime}$ di tambak TongkeTongke lebih tinggi daripada di tambak Pangasa. Perbedaan yang nyata $(P<0,05)$ hanya terlihat pada nilai E makrobentos di Tambak Pangasa dan di dasar Sungai Sinjai.
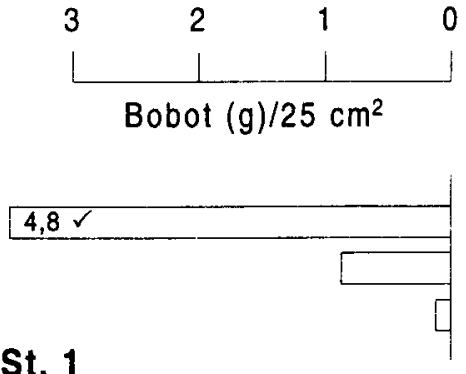

St. 1

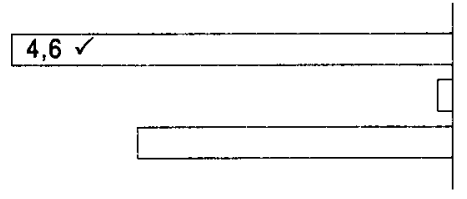

Cerithidea cingulata Phasionella australis Rhinoclavis aspera

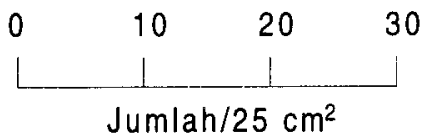

Cerithidea cingulata Phasionella australis $P$. actiophica

St. 2

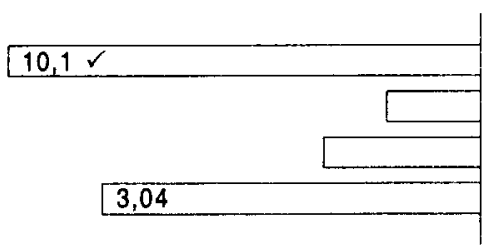

Cerithidea cingulata Placuna placenta Rhinoclavis aspera Sacostrea cucullata
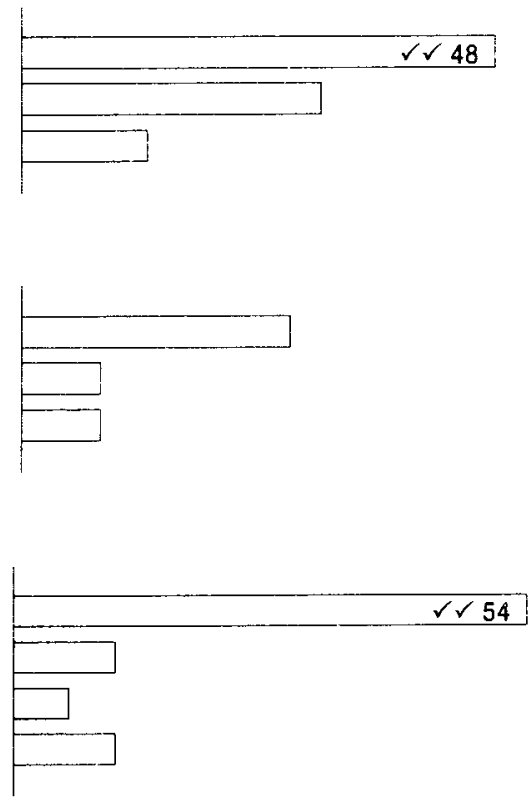

St. 3

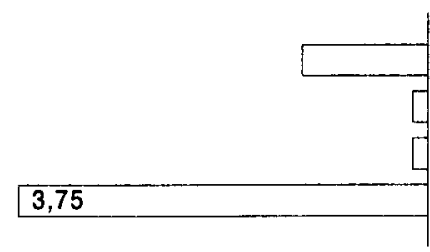

Cerithidea cingulata

Phasinella aethiophica

Tellina timorensis

Sacostrea cucullata

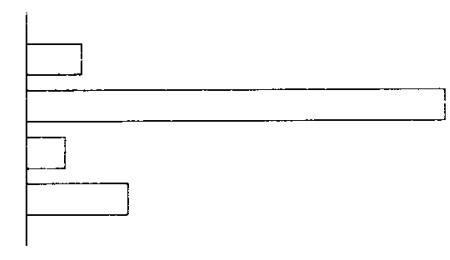

St. 4

Gambar 1. Komposisi dan kepadatan makrobentos di tambak (stasiun 1, 2, dan 3) dan mangrove (stasiun 4) di Dusun Pangasa, Desa Samataring, Kabupaten Sinjai

Figure 1. Composition and density of dwelling macrobenthos in brackishwater pond (station 1,2, and 3) and mangrove (station 4) in Dusun Pangasa, Samataring Village, Sinjai Regency

nilai $\mathrm{H}^{\prime}$ tertinggi $(0,54)$ dijumpai di stasiun 12 dan nilai C tertinggi $(0,55)$ dijumpai di stasiun 11 dengan komposisi makrobentos terdiri atas Placuna placenta dan Cerithidea cingulata dengan kepadatan masingmasing 10 ind. $/ \mathrm{m}^{2}$ dan 5 ind. $/ \mathrm{m}^{2}$ (Gambar 4).
Komposisi spesies, jumlah total individu dan biomas makrobentos dari perairan tambak, mangrove, dan sungai dapat dilihat di Gambar 1, 2, 3, dan 4.

Gambar 5 memperlihatkan bahwa di tambak Dusun Pangasa, Desa Samataring, kualitas tanah aktual 


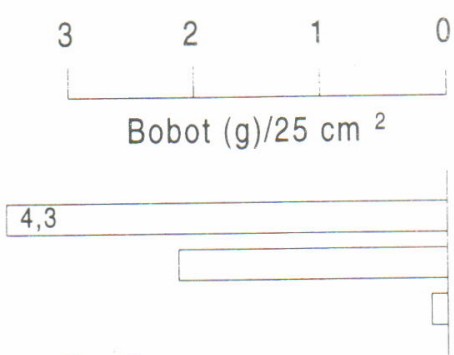

St. 5

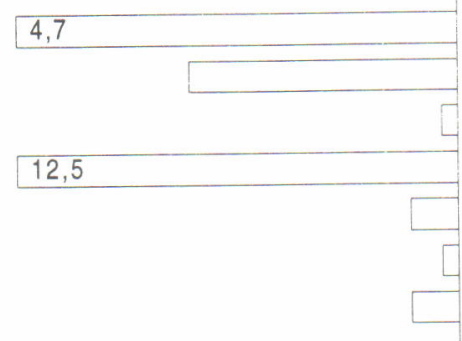

St. 6

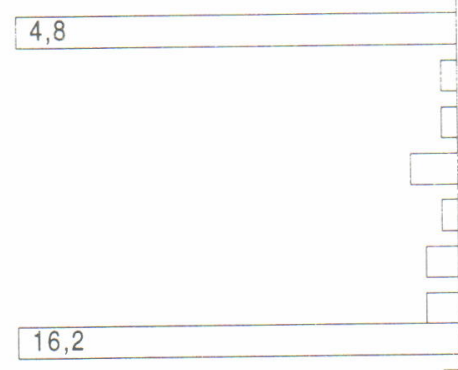

St. 7

$\frac{0 \quad 10 \quad 20 \quad 30}{\text { Jumlah } / 25 \mathrm{~cm}^{2}}$

Cerithidea cingulata Phasionella australis

P. actiophica

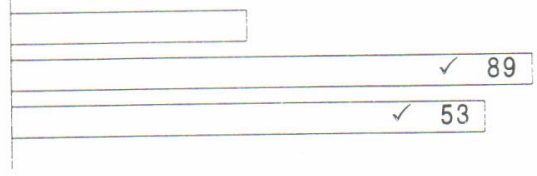

Cerithidea cingulata

Phasionella australis

$P$. actiophica

Clypeomorus corrallium

Chrysostoma paradoxum

Epitonidae

Saccostrea cucullata

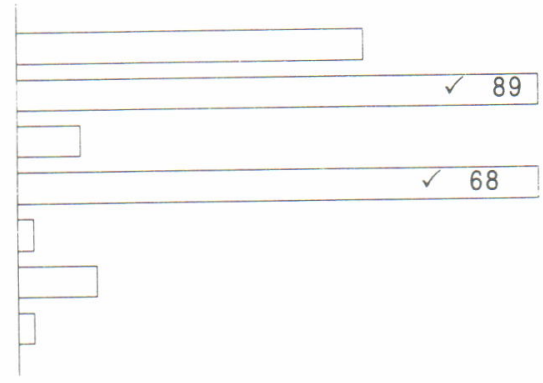

Cerithidea cingulata

Phasionella australis

P. actiophica

Dosinia insilarum

Mitra sp.

Neritina turrita

Pitar manillae

Rhinoclavis aspera

Tellina timorensis

Barliea rubra

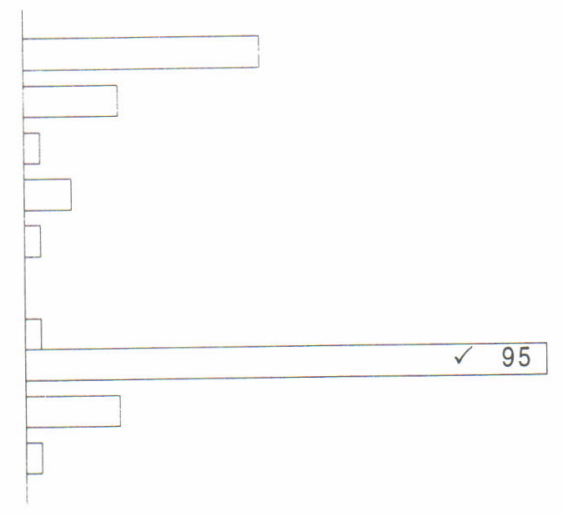

Gambar2. Komposisi dan kepadatan makrobentos di tambak Dusun Tongke-Tongke, Desa Samataring Kabupaten Sinjai, Sulawesi Selatan

Figure 2. Composition and density of dwelling macrobenthos in brackish water pond of Dusun TongkeTongke, Samataring Village, Sinjai Regency

semakin ke arah mangrove kandungan bahan organik tambak semakin tinggi yaitu dari 2,99\% (stasiun 1) hingga $6,47 \%$ (stasiun 3). Sedangkan di (stasiun 4) kandungan bahan organik sebanyak $9,36 \%$. Sejalan dengan hal itu juga kandungan debu dari arah tambak ke mangrove juga semakin meningkat yaitu dari 10\% (stasiun 1) hingga $48 \%$ (stasiun 4). Sedangkan kandungan pasir menunjukkan perbandingan terbalik yaitu semakin menurun ke arah mangrove yaitu dari $90 \%$ (stasiun 1) hingga 52\% (stasiun 4 ).

Gambar 6 memperlihatkan bahwa di tambak Dusun Tongke-Tongke, Desa Samataring, kandungan bahan organik memperlihatkan pola yang sama dengan di Dusun Pangasa, semakin tinggi ke arah mangrove yaitu dari 4,04\% (stasiun 5) hingga 9,5\% (stasiun 7).
Pada tanah hutan mangrove di sekitar garis pantai (stasiun 8), kandungan bahan organik paling tinggi yaitu mencapai $12,97 \%$; sedangkan semakin keluar semakin menurun yaitu hanya $5,71 \%$ (stasiun 10 ). $\mathrm{Hal}$ ini karena letak stasiun 10 langsung berbatasan dengan laut terbuka, maka kemungkinan bahan organik di permukaan tanah banyak terbawa ke laut lepas akibat hempasan arus pasang surut sehingga yang tertinggal di stasiun 10 selalu lebih sedikit dibandingkan di stasiun 8 dan 9. Pola yang sama juga ditunjukkan pada kandungan debu yaitu semakin meningkat ke arah mangrove dan menurun kembali di areal mangrove yang paling dekat dengan laut (stasiun 10). Kandungan pasir juga semakin menurun ke arah mangrove seperti yang terjadi di Pangasa 


\begin{tabular}{llll}
3 & 2 & 1 & 0 \\
\hline & 1 & 1 &
\end{tabular}

Bobot $(\mathrm{g}) / 25 \mathrm{~cm}^{2}$

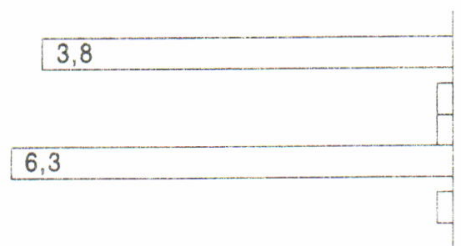

St. 8

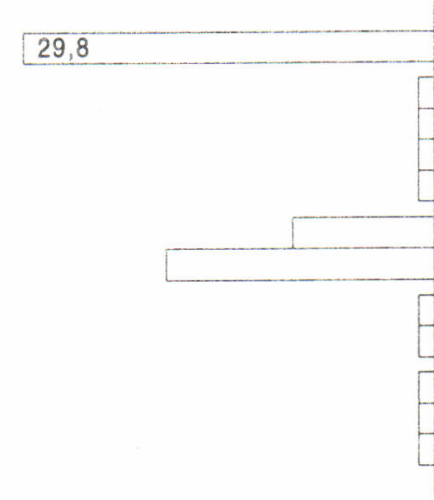

St. 9

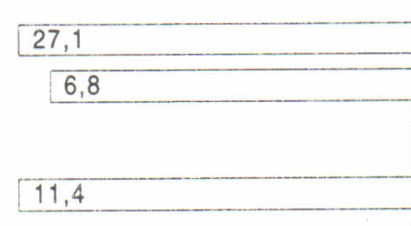

St. 10

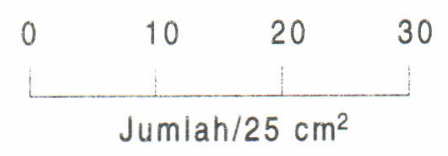

Saccostrea cucullata Vexillum $\mathrm{sp}$.

Barliea rubra

Clypeomorus corrallium

Pitar manillae

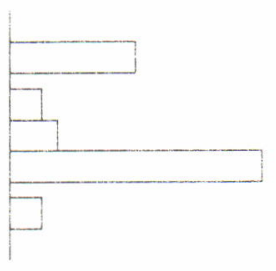

Saccostrea cucullata

Vexillum sp.

Pitar manillae

Berthelinea chloris

Cerithidea cingulata

Drupa musica

Gafrarium tumidum

Lopha cristagali

Neritina turnita

Phasionella australis

Smaragdia viridia

Tellina timorensis

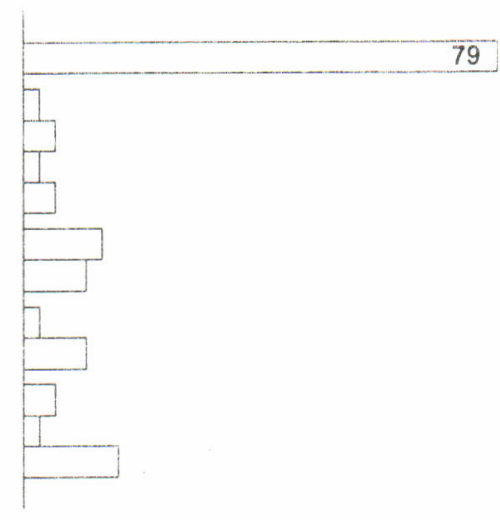

Saccostrea cucullata

Drupa musica

Neritina turnita

Tellina timorensis

Clypeomorus corallium

Dosinia insilarum

Perna viridis

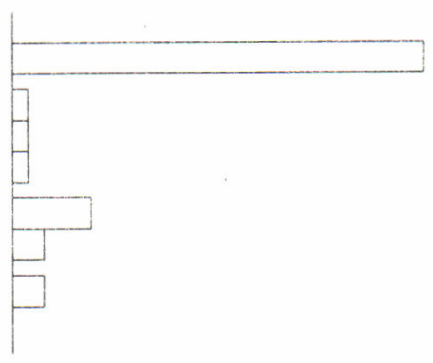

Gambar 3. Komposisi dan kepadatan makrobentos di hutan bakau Tongke-Tongke, Desa Samataring, Kabupaten Sinjai, Sulawesi Selatan

Figure 3. Composition and density of dwelling macrobenthos in Mangrove Tongke-Tongke, Samataring Village, Sinjai Regency

(stasiun 1 - stasiun 4), namun terjadi peningkatan kembali di stasiun 10. Hal ini kemungkinan karena stasiun 10 terletak langsung berbatasan dengan laut, maka lapisan bahan organik selalu hanyut oleh air pasang sehingga hanya pasir yang tertinggal di permukaan dasar mangrove.

Bahan organik merupakan sumber nitrogen tanah serta nutrien lainnya seperti C, P, trace element, dan vitamin. Unsur-unsur tersebut berperanan dalam proses oksidasi reduksi tanah. Pertumbuhan pakan alami berhubungan dengan kadar bahan organik tanah. Makin tinggi bahan organik tanah maka produktivitas tambak semakin meningkat. Kandungan bahan organik tanah yang layak bagi pertumbuhan pakan alami di tambak adalah 9\% (Hanafi et al., 1995). Dengan demikian tambak di Pangasa tingkat kesuburannya masih rendah karena kandungan bahan organik paling tinggi adalah $7,07 \%$ (stasiun 3), sedangkan di Tongke-Tongke hanya tambak yang berbatasan dengan hutan mangrove yang mempunyai kesuburan tinggi dengan kandungan bahan organik mencapai 9,5\% (stasiun 7). Dengan demikian nampak jelas bahwa ketebalan hutan mangrove akan sangat mempengaruhi tingkat kesuburan tambak yang terletak di sekitarnya. Diketahui bahwa hutan mangrove yang ada di Pangasa dengan ketebalan sekitar 


$\frac{3}{3} \frac{1}{2}$

St. 11

St. 12

St. 13

\section{Cerithidea cingulata}

Placuna placenta

Cerithidea cingulata

Foliatea tellin

Neritina turrita

Tellina timorensis

Saccostrea cucullata

Foliatea tellin

$\frac{0 \quad 10 \quad 20 \quad 30}{\text { Jumlah/25 } \mathrm{cm}^{2}}$
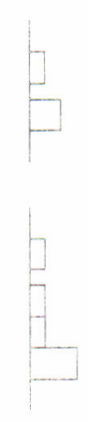

Gambar 4. Komposisi dan kepadatan makrobentos di Sungai Sinjai, Desa Samataring, Kabupaten Sinjai Figure 4. Composition and derisity of dwelling macrobenthos in Sinjai River, Samataring Village, Sinjai Regency

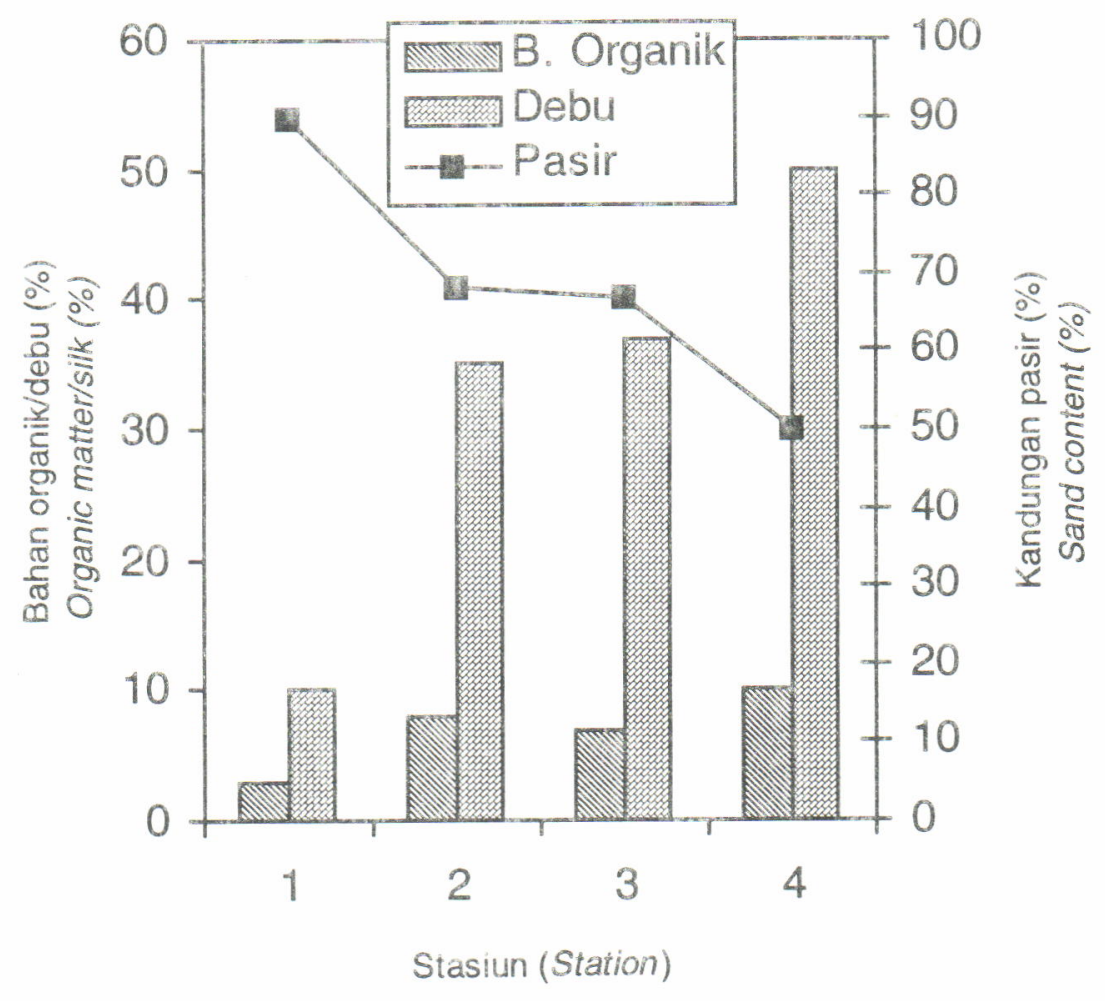

Gambar 5 . Hubungan antara persentase kandungan bahan organik dengan persentase debu dan pasir pada tanah tambak, dan tanah mangrove di Dusun Pangasa, Desa Samataring, Kabupaten Sinjai

Figure 5. The relationship among percentage of organic matter, silt and sand content of brackishwater pond and mangrove soil in Dusun Pangasa, Samataring Village, Sinjai Regency 
25 m dan hanya sekitar 1 ha. Sedangkan hutan mangrove yang ada di Tongke-Tongke dengan ketebalan $300 \mathrm{~m}$ dengan luas sekitar $600 \mathrm{ha}$.

Apabila dibandingkan di antara areal lokasi penelitian yaitu antara tambak Pangasa, tambak Tongke-Tongke, mangrove Tongke-Tongke, dan Sungai Sinjai; maka ' $\mathrm{H}^{\prime}$ makrobentos tertinggi adalah di tambak Tongke-Tongke $(0,47)$. Hal ini terbukti dengan lebih beragamnya spesies makrobentos yang diperoleh di tambak Tongke-Tongke (Gambar 2) daripada di tambak Pangasa (Gambar 1) dan di Sungai Sinjai (Gambar 4). Beragamnya spesies makrobentos di tambak Tongke-Tongke kemungkinan hasil ekspansi dari beragamnya makrobentos yang ada di hutan mangrove Tongke-Tongke (Gambar 3). Sedangkan nilai E makrobentos tertinggi didapatkan di Sungai Sinjai $(0,94)$ dan nilai $\mathrm{C}$ makrobentos tertinggi didapatkan di tambak Pangasa $(0,55)$ (Tabel 2).

Dari Lampiran 1 dapat dilihat bahwa pH KCL dan $\mathrm{pH}_{2} \mathrm{O}$ tanah sudah cukup bagus yaitu pada kisaran $6,2-7,37$; namun kandungan $\mathrm{Fe}$ terlihat sangat tinggi $(>100 \mathrm{mg} / \mathrm{L})$ di beberapa stasiun kecuali di stasiun 8 dan 10. Menurut Dent (1986), tanah sulfat masam yang sudah tua sebagian besar kandungan besi dalam bentuk kristal goetite dan haematite. Sedangkan pada tanah sulfat masam yang masih muda kandungan besi akan berbentuk koloidal yang akan menghasilkan kandungan besi dalam air cukup tinggi pada waktu banjir. Kandungan besi dalam tanah tidak akan terus tinggi konsentrasinya, tetapi dalam beberapa minggu akan menurun dengan sendirinya karena tereduksi menjadi bentuk lain.

Kandungan $\mathrm{SO}_{4}$ sangat tinggi hampir di seluruh stasiun yaitu pada kisaran 1290,43 - 2571,85 mg/L. Kandungan $\mathrm{Fe}$ dan $\mathrm{SO}_{4}$ yang tinggi, maka potensial untuk terbentuknya pyrit dan jarosit yang dapat menyebabkan lahan tambak menjadi asam ( $\mathrm{pH} 2,5$ hingga pH 5). Keasaman lahan timbul setelah tambak selesai dibangun disebabkan terjadi pemecahan senyawa pyrit setelah tanah dasar tambak terjemur. Keasaman lahan dapat diturunkan melalui proses reklamasi tambak yaitu melalui proses penjemuran, perendaman, pencucian secara berulang-ulang, dan selanjutnya dilakukan pengapuran (Poernomo, 1988).

Dari Lampiran 2 dapat dilihat bahwa pada bulan Oktober 2001, salinitas di perairan Desa Samataring cukup tinggi yaitu mencapai $35-41 \mathrm{ppt}$, hal ini karena masih berlangsung musim kemarau. $\mathrm{pH}$ pada kisaran $7,32-8,44$. Alkalinitas air tambak dan sungai berdasarkan kriteria dari Swingle (1968) termasuk dalam katagori alkalinitas sedang karena nilainya sekitar 68-100. Kandungan $\mathrm{Fe}$ air cukup tinggi yaitu pada kisaran 0,505 - 0,597 mg/L. Menurut Boyd (1990), kandungan Fe di perairan antara 0,05-0,2 $\mathrm{mg} / \mathrm{L}$. Dengan demikian kandungan Fe baik di perairan Tambak Pangasa dan Tongke-Tongke maupun di Sungai Sinjai cukup tinggi. Hal ini kemungkinan karena pengaruh dari kandungan Fe di lahan daerah tersebut juga tinggi yaitu pada kisaran $56,15-475,35$ $\mathrm{mg} / \mathrm{L}$ (Lampiran 1).

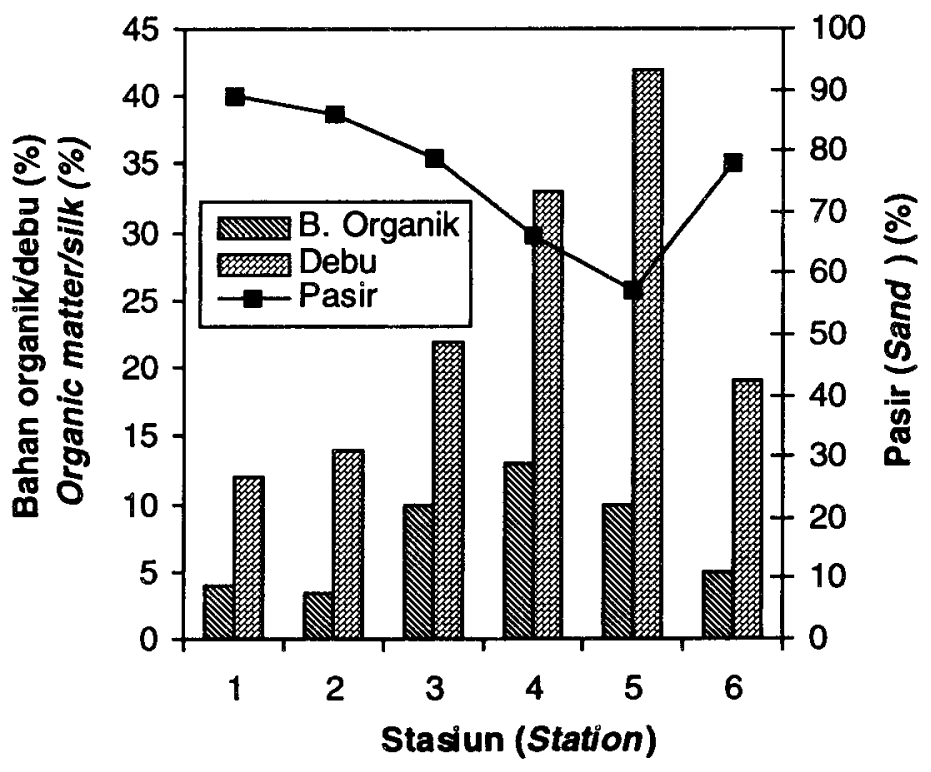

Gambar 6. Hubungan antara persentase kandungan bahan organik dengan persentase debu dan pasir pada tanah tambak dan tanah mangrove di Dusun Tongke-Tongke, Desa Samataring, Kab. Sinjai

Figure 6. The relationship among percentage of organic matter, silt, and sand content of brackishwater pond and mangrove soil in Dusun Tongke-Tongke, Samataring Village, Sinjai Regency 
Kandungan $\mathrm{NH}_{3}-\mathrm{N}$ baik di Tambak Pangasa dan Tambak Tongke-Tongke juga cukup tinggi yaitu antara $0,181-0,184 \mathrm{mg} / \mathrm{L}$. Menurut Chin \& Chen (1987), kandungan $\mathrm{NH}_{3}-\mathrm{N}$ yang layak untuk kehidupan jasad akuatik di tambak adalah kurang dari $0,13 \mathrm{mg} / \mathrm{L}$. Kandungan $\mathrm{NO}_{2}-\mathrm{N}$ dan $\mathrm{NO}_{3}-\mathrm{N}$ masih dalam tingkatan yang wajar yaitu masih rendah pada kisaran 0,039$0,072 \mathrm{mg} / \mathrm{L}$ dan $0,018-0,020 \mathrm{mg} / \mathrm{L}$. Sedangkan kandungan $\mathrm{PO}_{4}-\mathrm{P}$ cukup tinggi yaitu pada kisaran $0,178-0,228 \mathrm{mg} / \mathrm{L}$. Ahmad et al. (2001) menyatakan bahwa kelebihan fosfat dan nitrat akan direduksi oleh tanaman mangrove dan organisme asosiasinya seperti plankton dan bentos.

\section{KESIMPULAN}

Nilai H' makrobentos di tambak dan hutan mangrove Dusun Tongke-Tongke cenderung lebih tinggi daripada di tambak Pangasa, namun tidak menunjukkan perbedaan yang nyata $(P>0,05)$; perbedaan nyata $(P<0,05)$ justru nampak pada nilai E makrobentos di tambak Pangasa dan di dasar Sungai Sinjai. Sedangkan nilai $C$ tidak menunjukkan perbedaan yang nyata $(P>0,05)$ di semua lokasi penelitian.

Baik di tambak Dusun Pangasa maupun di tambak Dusun Tongke-Tongke, Desa Samataring, kualitas tanah aktual semakin ke arah mangrove kandungan bahan organik tambak semakin tinggi, begitu juga kandungan debunya. Sedangkan kandungan pasir semakin menurun ke arah mangrove.

Keberadaan areal mangrove yang luas di sekitar tambak dapat menyebabkan keragaman makrobentos dan kandungan bahan organik di tambak menjadi lebih tinggi bila dibandingkan dengan tambak yang di sekitarnya hanya mempunyai areal mangrove yang sempit.

\section{DAFTAR PUSTAKA}

Abbot, T. R. 1992. Seashells of South East Asia. Tynron Press, Scotland $145 \mathrm{pp}$.

Ahmad, T. 1999. The use of mangrove stand for shrimp pond waste-water treatment. IFR Journal (7) 1: 7-15.

Ahmad, T., M. Tjaronge, dan F. Cholik. 2001. The use of mangrove stands for shrimp pond waste-water treatment. IFR Journal 7 (1): 7-15.

Anonim. 2001. Kriteria dan Standar Teknis Rehabilitasi Hutan Mangrove. (Draft - 2). Direktorat Jenderal Rehabilitasi Lahan dan Perhutanan Sosial. Direktorat Rehabilitasi Lahan dan Konservasi Tanah, Departemen Kehutanan. 79 pp.
Boyd, C.E. 1990. Water Quality in Ponds for Aquaculture. Department of Fisheries and Allied Aquacultures. Auburn University Alabama. $92 \mathrm{pp}$.

Chin, T.S. dan J.C. Chen. 1987. Acute toxicity of amonia to larva of the tiger prawn, Penaeus monodon, Aquaculture 66: 247-253.

Dent, D. 1986. Acid sulfat soil: A baseline for research and development. International Institute for Land Reclamation and Improvement/ILRI, Wageningen, Netherland. $32 \mathrm{pp}$.

Dharma, B. 1988. Siput dan Kerang Indonesia I (Indonesian Shells I). PT Sarana Graha, Jakarta, 111 pp.

Dharma, B. 1992. Siput dan Kerang Indonesia II (Indonesian Shells (I). Verlag Christa Hemmem, Germany, $134 \mathrm{pp}$.

Fowler, J. dan L. Cohen. 1990. Practical Statistic for Field Biology. Open University Press. Philadelphia. p. 180185.

Haryadi, S., I.N.N. Suryodiputro, dan B. Widigdo. 1992. Limnologi. Penuntun praktikum dan metode analisa air. Institut Pertanian Bogor. Fak. Perikanan. 57 pp.

Hanafi, A., A. Mustafa, dan B. Pantjara. 1995. Pertumbuhan kepiting bakau, bandeng, dan nila merah di tambak tanah gambut. Jurnal Penelitian Perikanan Indonesia I (1): 26 - 35.

Menon, R.G. 1973. Soil and Water Analysis. A Laboratory manual for the analysis of soil and water. Food Agricultural Organisation. United Nations Development Programme. $191 \mathrm{pp}$

Melville, M.D. 1993. Soil Laboratory Manual. School of Geography. University of New South Wales. 74 pp.

Odum, E.P. 1963. Ecology, Second Edition. Holt, Rinehart and Winston, Inc All Rights Reserve. 243 pp.

Odum, E.P. 1971. Fundamental of Ecology. Third edition, W.B. Sounders Co. Philadelphia and London, $546 \mathrm{pp}$.

Poernomo, A. 1988. Pembuatan Tambak Udang di Indonesia. Seri Pengembangan No. 7. Badan Penelitian dan Pengembangan Pertanian, Departemen Pertanian. 30 pp.

Rejeki, S. dan T. Ahmad. 1991. Kelimpahan plankton dan makrobentos di padang lamun Desa Margagiri, Teluk Banten. Prosiding Pertemuan Teknis Pelestarian Lingkungan Hidup Perikanan, Jakarta. 11 Pebruari 1991. p. 169-179.

Sarpedonti, V. and A. Sesakumar. 1997. The macrobenthic community in the mangrove estuarin matang, Perak. In. Shigeo Hayase Eds. Productivity and sustainable utilization of brackish water mangrove ecosystems. Proceeding of the $2^{\text {nd }}$ Seminar on Results for 1995/1996 Research Projects. Japan International Research Center for Agricultural Sciences, Ministry of Agriculture, Forestry and Fisheries. p. 13-23.

Swingle, H.S. 1968. Standardization of Chemical Analysis for Water Pond Muds. FAO Fish. Rep. p. 397-406. 


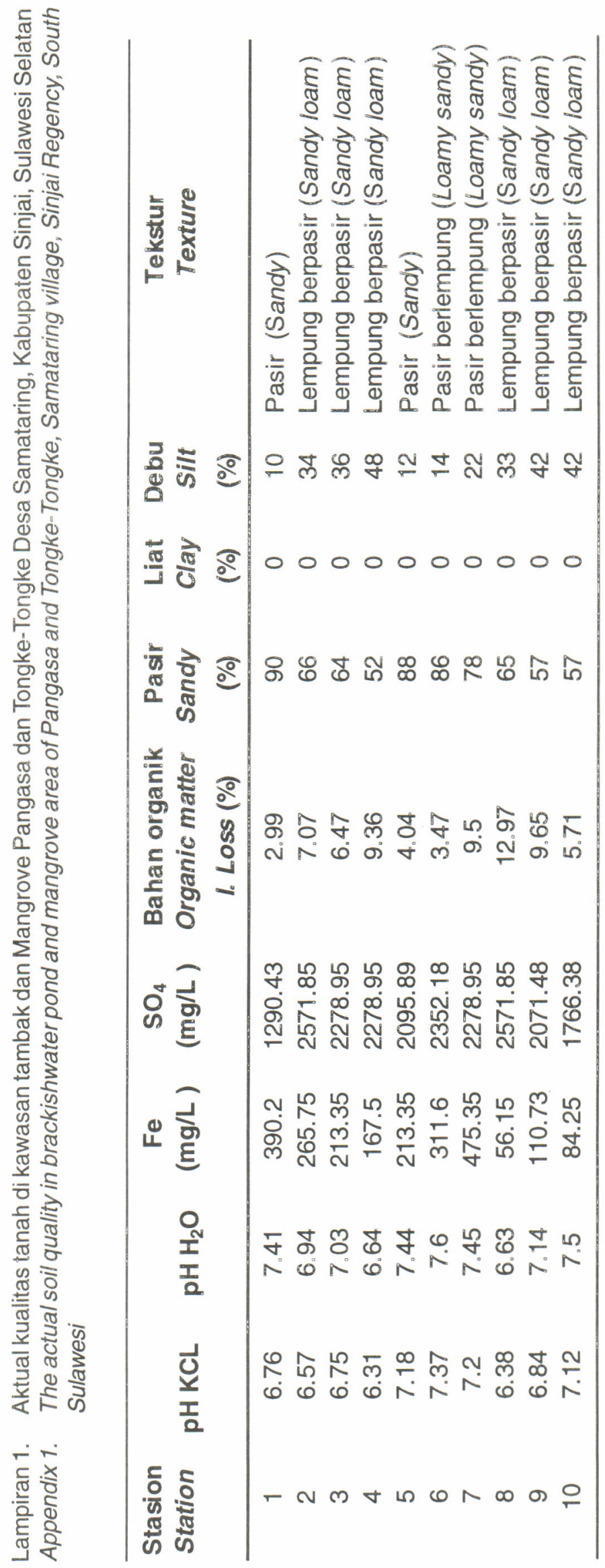




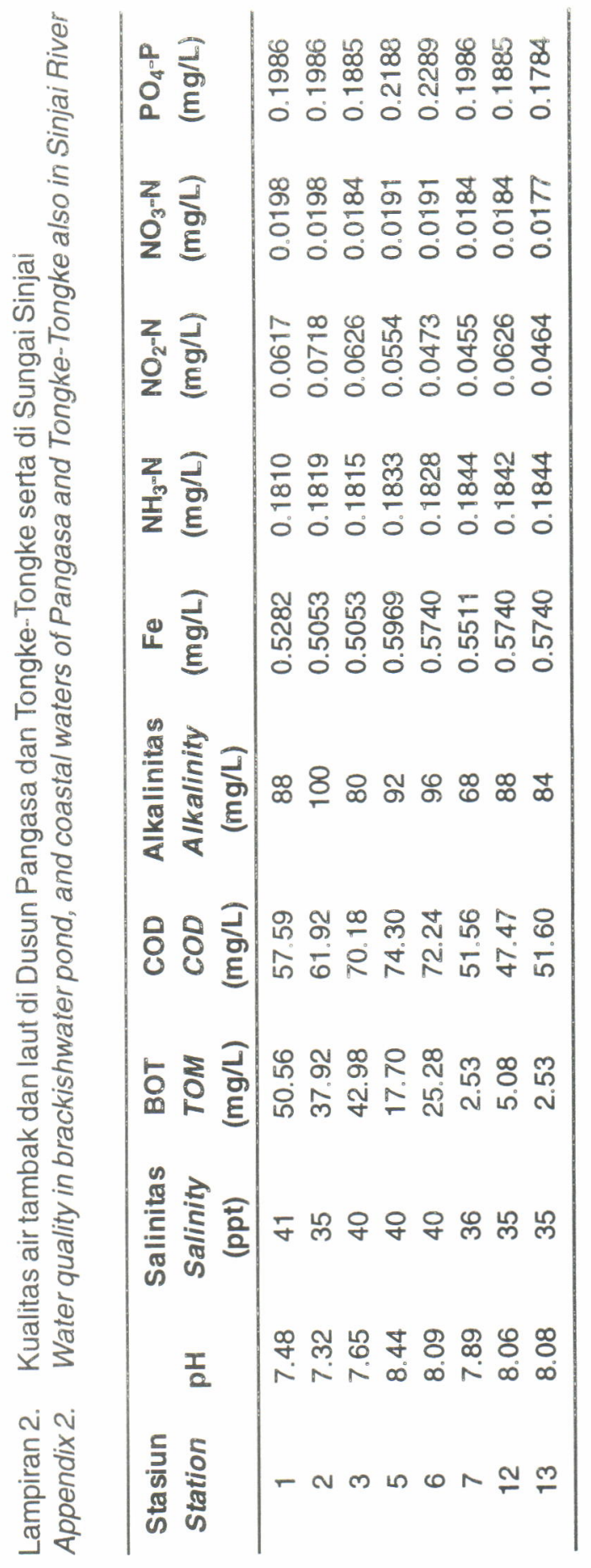

